\title{
Stability and increasing fluidity in the contemporary Japanese social stratification system *
}

YOSHIMICHI SATO

Abstract

We argue that stability and increasing fluidity coexist in the contemporary Japanese social stratification system. It is often argued that the weakening of Japanese employment practices has made the labor market more flexible. While there is evidence to support this argument, it misses an important factor in the labor market, namely social stratification. We suggest that some parts of the labor market have become more fluid, while other parts have been stable. To test this prediction, we examine empirical findings made in the 2005 Social Stratification and Social Mobility Survey Project, covering such topics as education and inequality, increasing fluidity and disparity among young workers, job changes, and income inequality. Our findings on education and inequality show that stratification in the educational system affects the entry of graduates into regular or non-regular employment. Our analysis of young workers shows that while the longterm employment practice persists in large firms and the public sector and thus shows stability, mobility between regular and non-regular employment is difficult and that young female graduates from high schools and junior colleges recently find it difficult to enter the regular employment sector. Our analysis of the effect of education on job changes shows that the income of less educated workers who change jobs has decreased recently. We also find increasing income inequality between professionals and other occupations and examine the intergenerational transmission of income. We conclude that these findings generally support our prediction that stability and increasing fluidity coexist in the contemporary Japanese labor market. We consider the implications of this for the study of social stratification in Japan.

Keywords: social stratification; fluidity; stability. 


\section{The coexistence of stability and increasing fluidity in the social stratification system}

We argue that stability and increasing fluidity coexist in the contemporary Japanese social stratification system. It is often argued that the weakening of Japanese employment practice has made the labor market more flexible. While there is evidence to support this argument, it misses an important factor in the labor market, namely social stratification. We predict that some parts of the labor market have become more fluid, while other parts have remained stable. This prediction is derived from our assumption that protective institutions in the labor market have their own inertia (Sato and Arita 2008). Inertia of a local institution refers to how irresponsive it is to global factors such as globalization and neoliberal policies. A local institution has small inertia if it quickly responds to global factors, while it has large inertia if it slowly or not at all responds to them.

We argue that protective institutions in the internal labor market have larger inertia than those in the external labor market. This is because employers in the internal labor market still need, or at least believe they need, "core employees" to work for them until retirement. ${ }^{1}$ In addition to this, labor unions in the internal labor market are eager to maintain the job security of their members, even though their influence has been declining. In contrast, employers in the external labor market find it more difficult than before to provide their employees with job security, and labor unions are politically weak or do not exist in the external labor market.

It is therefore predicted that this differential inertia, which is created by class strategies (Ishida and Slater 2010) of various social classes in the labor market, produces the coexistence of stability in the internal labor market and increasing fluidity in the external labor market. Furthermore, people in higher strata dominate in the internal labor market, while people in lower strata are pushed to the external labor market. Thus this prediction leads to another prediction, namely that the working and living conditions of people in lower strata have been deteriorating because of increasing fluidity in the external labor market.

In this paper we present evidence that supports these theoretical predictions. The evidence comes from findings of the 2005 Social Stratification and Social Mobility Survey Project (SSM) (Principal Investigator: Sato Yoshimichi). This project studies social stratification, social mobility, and inequality using data sets obtained by nationwide surveys conducted every decade since 1955. In the 2005 SSM Project we hypothesized that stability and fluidity coexist in the labor market, based on theories of the dual labor market in Japan (Odaka 1984; Kalleberg and 
Lincoln 1988; Nomura 1994). What we found by analyzing the data sets, however, is not fluidity but increasing fluidity and, therefore, the coexistence of stability and increasing fluidity. Theories of the dual labor market, which focus on differences between small and midsize firms and large firms, seem to have implicitly assumed that most workers have regular jobs. However, the sharp increase in the number of non-regular workers as well as the emergence of new types of non-regular workers such as temporary employees has led to increasing fluidity. Thus we need to differentiate between the regular and non-regular employment sectors to properly analyze the coexistence of stability and increasing fluidity in the dual labor market (Imai and Sato, forthcoming).

From this perspective, in the following sections we will discuss education and inequality, increasing fluidity and disparity among young workers, job changes, and income inequality, ${ }^{2}$ in order to fully understand the current situation of inequality and social stratification in contemporary Japan.

\section{Education and inequality}

Two topics will be discussed in this section: transition from school to work and entry into regular/non-regular employment. The implicit contract is an informal relationship between local schools and firms that facilitates the smooth transition from school to work (Kariya 1991). Teachers exchange information with company recruiters on high school students and job openings. Teachers then recommend particular students for jobs in particular firms with an implicit guarantee for the students, and the firms hire the recommended students trusting the teachers' evaluation of them. The implicit contract is supported by trusting relationships between teachers and recruiters and the efficient exchange of information about students and jobs. It is a key to the low unemployment rates of young people in Japan compared to their counterparts in other advanced societies.

Honda (2005), however, argues that the implicit contract is weakening. This argument seems reasonable, because firms can no longer maintain the contract due to their exposure to increasing fluidity in the labor market, thus explaining why many high school students find it difficult to get a regular job upon graduation. Using SSM data sets, Brinton (2008) analyzed the processes by which young people enter their first jobs. She compared three graduation cohorts: the older cohort (graduating from school before 1978), the bubble-economy cohort (graduating from school between 1978 and 1991), and the post-bubble-economy cohort (graduating from school between 1992 and 2005). The proportion of those who got a job by implicit contract was 40.4 percent in the pre- 
bubble-economy cohort, 41.91 percent in the bubble-economy cohort, and 37.59 percent in the post-bubble-economy cohort. Although the proportion for the post-bubble-economy cohort is smaller, the difference to the other cohorts is not statistically significant. This means that the implicit contract has not necessarily been weakening.

By using entry to regular employment as the dependent variable in logistic regression analysis, Brinton (2008) also shows that those who got a job through implicit contract are more likely to get a job within a month of graduation and to get a regular job than those who directly apply for work through job advertisements. This result shows that an implicit contract is still a powerful tool with which to get a regular job upon graduation. Furthermore, it also suggests that young people who are unable to use the implicit contract find it more difficult than before to obtain a regular job in the contemporary labor market. This is because non-regular employment accounts for an increasing share of the market.

Entry to regular employment is also affected by educational stratification. Better-educated people are more likely to enter regular employment (Brinton 2008). Using the 2005 SSM data set, Hirata (2008) shows that less-educated people are more likely to enter non-regular employment and have been more exposed to the negative impacts of the recession since 1992. Many specialists in the study of young part-time workers (freeters in Japanese), such as Kosugi $(2002,2003)$, point out that lesseducated people are more likely to become freeters, a finding that supports the conclusions of Brinton and Hirata.

These findings show that stability and increasing fluidity coexist in contemporary Japanese educational stratification. On the one hand, well-educated people and those who are able to use an implicit contract have an advantage in getting a regular job. On the other hand, those who are unable to use an implicit contract tend to enter non-regular employment. In addition, as will be shown, once a person enters nonregular employment, he/she tends to stay in that sector. Thus we argue that the upper educational strata enjoy stability, while the lower educational strata are involved in the turmoil of the fluid labor market.

\section{Increasing fluidity and disparity among youth}

It is young people who are most deeply affected by the increasing fluidity of the labor market in Japan. Mass media often focuses on the difficulties faced by young workers, who are often characterized as freeters, NEETs, and working poor. ${ }^{3}$ This section examines the situation of young workers from the viewpoint of social stratification.

Long-term employment is still prevalent in large firms and the public sector. Using event history analysis, Nakazawa (2008) analyzed the effect 


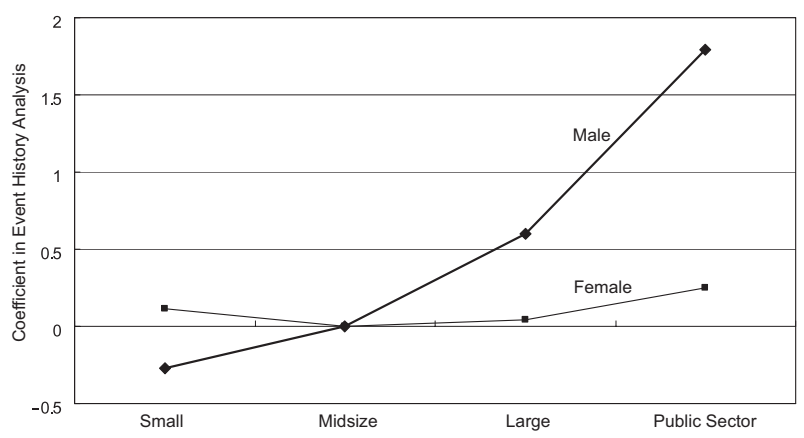

Figure 1. The effect of company size on duration of first job. Source: Based on Nakazawa (2008: 128, Table 5).

of stratification variables on the duration of a young person's first job. Figure 1 displays the coefficient of firm size by gender after controlling for other variables. The coefficient for the midsize firm is 0 because this is the reference category. Thus a positive (negative) coefficient for another category means a longer (shorter) duration in the first job compared to midsize firms. Because the coefficients for large firms and the public sector are positive in the case of male workers, men who get their first job at large firms or in the public sector tend to hold the job longer than their counterparts in small and midsize firms. The figure also clearly shows the gender difference in the duration of a young person's first job. Coefficients for female workers at large firms and the public sector are not as large as those of their male counterparts.

Those who enter the public sector for their first job recently also tend to stay there for longer (Nakazawa 2008). Nakazawa's comparison of the duration of first job between entry cohorts shows that those who entered the sector after 1992 had a stronger tendency to stay than cohorts entering the sector before 1992. This may indicate that people in the more recent entry cohort stayed in their first public sector job because it would be difficult for them to get a better job elsewhere.

These results imply that the long-term employment practice is still prevalent in the core of the labor market, but it is more difficult for young people to obtain regular employment upon graduation. Thus a disparity emerges between those who enjoy high job security and those who manage to enter only unstable jobs. Because well-educated people are more likely to get a job at large firms and in the public sector, Nakazawa's findings suggest increasing inequality of job security between educational strata.

Nakazawa analyzed the core of the dual labor market in Japan. Graduates who first obtain only non-regular jobs find it difficult to move into 


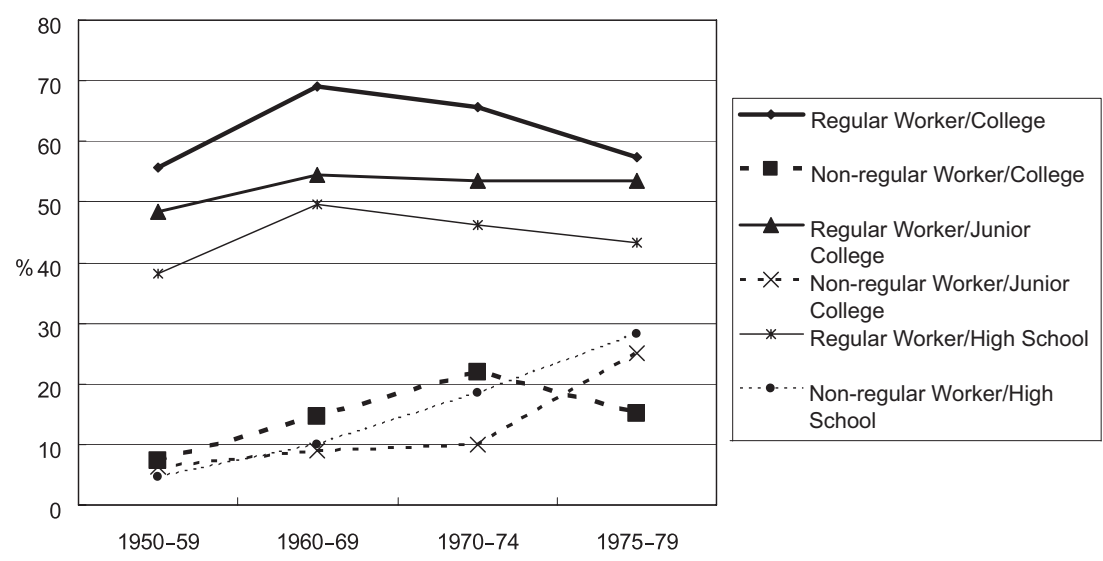

Figure 2. Proportions of female regular/non-regular workers by education and birth cohort.

Source: Based on Iwai (2008: 94, Table 2).

regular employment. Sato Kaoru (2008) confirmed this by analyzing the effect of entering non-regular jobs on occupational career trajectories. Her analysis shows that if a person's first job is non-regular, there is an increased possibility that the person's current job is also non-regular. This is the case both for men and women.

Increasing fluidity is also occurring in the early life courses of Japanese women. Iwai (2008) shows that the life course of women has become more diversified. He calculated the proportion of female regular and non-regular workers at the age of 25 by birth cohort and education. Figure 2 demonstrates that the proportion of women with regular jobs declined between the 1960-1969 birth cohort and the 1975-1979 birth cohort, with the exception of junior college graduates. The figure also shows that, in the case of the youngest cohort, the proportions of nonregular workers for high school and junior college graduates increase, while for college graduates it decreases. These results reflect the increasing difficulty of getting a regular job for young Japanese women regardless of education, as well as the increased risks associated with entering non-regular employment for young less-educated women.

These findings suggest that the increase in the share of non-regular workers and the increasing fluidity of employment do not occur ubiquitously in the youth labor market. Well-educated workers tend to be still under the protection of the long-term employment practice, while lesseducated workers tend to be trapped in the periphery of the labor market as non-regular workers during the prolonged recession. Therefore we should not study young workers as a homogeneous group. Rather, the coexistence of stability and increasing fluidity should be emphasized. 


\section{Heterogeneous situations surrounding job changers}

Increasing fluidity in the labor market naturally leads to the study of job changes. Nobody has the same probability of changing jobs; some people with particular stratification characteristics may have a higher probability than other people. Thus in this section we focus on job changes from the viewpoint of social stratification. From this perspective we explore changes in the long-term employment practice over time, as well as the meaning of occupational licenses and certificates in the labor market.

Although the weakening of the long-term employment practice has led to an increase in the number and frequency of job changes, there is evidence to suggest that this weakening has not occurred ubiquitously across social strata. There are important differences in stratification characteristics between those who stay in their jobs and those who change. To analyze the effect of firm size and occupation on long termemployment practice, Inada (2008) calculated the proportion of workers in the long-term employment practice among white-collar workers at large firms, white-collar workers at small and midsize firms, blue-collar workers at large firms, and blue-collar workers at small and midsize firms by entry cohort. The calculation reveals that the percentage of workers in the long-term employment practice declined for all groups between the 1976-1985 entry cohort (i.e., the youngest cohort) and the 1966-1975 entry cohort, suggesting that the long-term employment practice has recently weakened. What is more important, however, is that this decline is steeper for workers at small and midsize firms than for those at large firms. Inada's calculation shows that the weakening of the long-term employment practice has not occurred ubiquitously in the labor market. In other words, the gap between small/midsize and large firms has become wider in terms of the long-term employment practice.

Hirata's (2008) event history analysis reveals that women are more likely than men to leave their first job, and non-regular workers are more likely than regular workers to leave their job. Workers at larger firms and in the public sector in particular are less likely to leave their job. These findings complement those of Nakazawa (2008) above.

If a person changes jobs to improve his or her working conditions, there is no problem. But Yoshida (2008a) shows that changing jobs at an early stage of career development generally results in a reduction of income. He also shows that if a person changes jobs within three years of getting the first job, he or she mitigates to a degree the negative effect on their income so long as they do not leave the job afterward. However, according to Yoshida, it is difficult to hold on to the second job.

Hayashi (2008) calculated the proportion of job changes that resulted in income reduction across educational strata. Figure 3 shows how this 


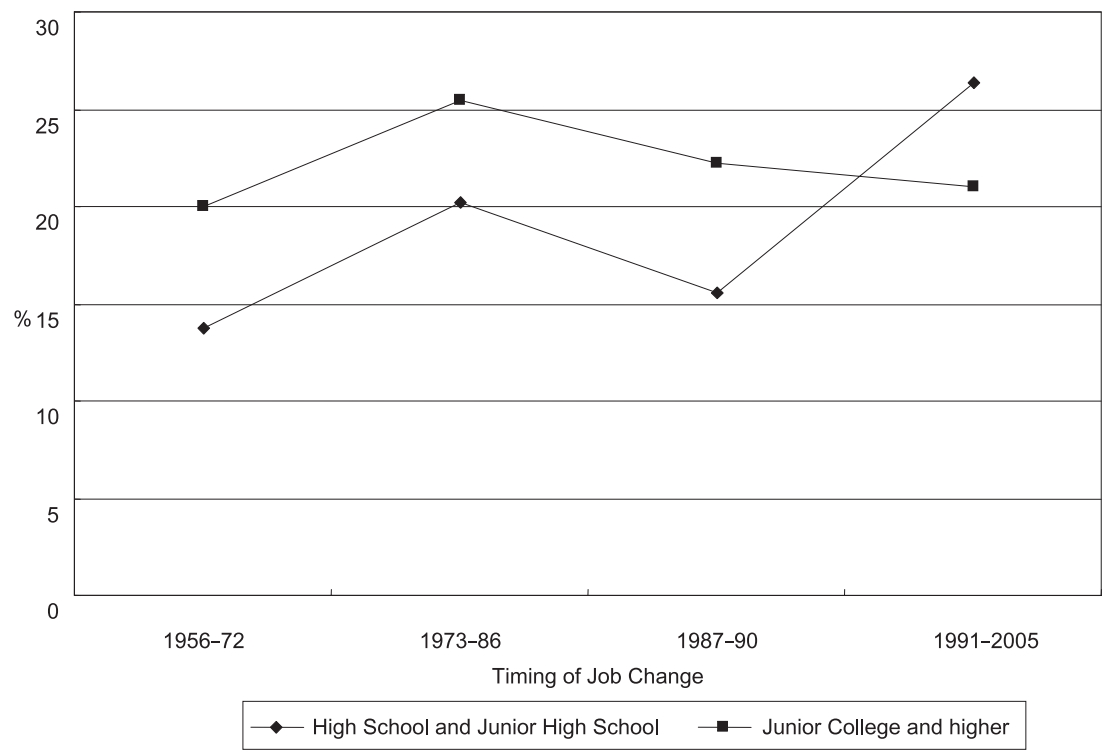

Figure 3. Proportion of job changes resulting in income reduction across educational strata and over time.

Source: Based on Hayashi (2008: 64, Table 2).

proportion changed over time. The proportion of job changes resulting in income reduction was higher for the well-educated group until 19871990, although the difference between the two groups was not statistically significant. However, in 1991-2005 the proportion for the lesseducated group was higher, and the difference is statistically significant. This means that the effect of education on job changes resulting in income reductions has strengthened recently, as less-educated job changers are dragged down into the turmoil of the fluid labor market.

The above-mentioned findings demonstrate the worsening objective conditions surrounding job changers. And, subjectively, job changers recognize the worsening situation in the labor market. Kanbayashi (2008) calculated the proportion of job changes for the reason "I found a better job" by birth cohort and year. The proportion of men who changed jobs in their 20s was lower for the younger cohort. This suggests that the situation of job changers has recently worsened.

Even voluntary job changes can result in a worsening of working conditions. According to theories of labor economics, when the unemployment rate is high, involuntary job changes such as layoffs increase while voluntary job changes decrease. Takenoshita (2008) shows that the unemployment rate increased voluntary as well as involuntary job changes 
during 1986-2005, but did not affect either in 1953-1985. He attributes this to the following mechanism: Normally, if a worker found a job he (or she) preferred, he would not readily take it, even if his current workplace was not very good. However, mismatch between workers and jobs frequently occurred among young workers during the 1990s, a period of prolonged recession. Because of this mismatch, even slight dissatisfaction with workplace conditions would drive workers to change jobs.

Under these fluid labor market conditions workers need "weapons" to protect themselves. Job certificates and licenses are examples of such weapons. Agata (2008) examined whether workers use certificates and licenses that are relevant to their occupation. His logistic regression analysis with use/non-use as the dependent variable shows that less-educated workers use their certificates and licenses more effectively. Based on this result, he argues that "while well-educated people are likely to have opportunities for better jobs without certificates and licenses, lesseducated people tend to develop their careers by getting relevant certificates and licenses because they cannot rely on their school diplomas" (Agata 2008: 98). In other words, degrees of higher education are still effective even in the fluid labor market, providing further evidence of the stability in the core of the labor market.

These findings demonstrate the coexistence of stability and increasing fluidity in the circumstances surrounding job changes. As Inada (2008) points out, the long-term employment practice has not weakened in large firms as rapidly as in small and midsize firms. In the external labor market, however, job changes with income reductions occur more frequently, and the reasons for job changes become worse. Job changers of this kind tend to be workers at small and midsize firms and non-regular workers, many of whom try to improve their standing in the harsh labor market by getting certificates and licenses.

\section{Widening income disparity and immobility}

Analysis of income using the SSM data set shows a mild increase in inequality of household income from 1995 to 2005 (Aizawa and Miwa 2008; Kanomata 2008). Analysis of income inequality between occupations shows that the gap of income between professionals and other occupations has widened (Sato Yoshimichi 2008; Nagamatsu 2008). Nagamatsu explains this by two mechanisms. First, the demand for highly skilled labor has increased, while that for low-skilled labor has decreased. This mechanism is called the skill-biased technological change hypothesis. Second, the wage of low-skilled labor has been suppressed due to harsh competition between firms. 
While income inequality reveals inequality of outcome, inequality of income transmission over generations captures inequality of opportunity to earn an income. Using the 1995 and 2005 SSM data sets and by estimating the father's income, Yoshida (2008b) created an intergenerational mobility (transmission) table of income. He divided income distribution by quartiles and created the transmission table by year and birth cohort. His analysis reveals a strong association between the father's and the child's income for the lowest and the highest strata. In addition, in the case of respondents aged 45-54 who have almost accomplished their occupational attainment, the association became stronger at the lowest as well as the highest stratum, and the rate of change towards stronger association is steeper for the highest stratum than that for the lowest stratum.

The above-mentioned analyses of income in this section show increasing inequality and immobility. The income of professionals has increased relative to that of other occupations; intergenerational transmission of income is fixed at the highest and the lowest strata; and the transmission has become more immobile at the highest strata in particular.

\section{Heterogeneous changes in the stratification structure}

We have examined findings from the 2005 SSM Project focusing on education and inequality, increasing fluidity and disparity among young workers, job changes, and income inequality. Based on these findings, we could argue that some parts of the social stratification system are still under protective institutions, while other parts of it are showing signs of increasing fluidity. We argue that strata in the core of the labor market are stable, while the level of fluidity is increasing in the periphery, based on such phenomena as the strength of the implicit contract, the widening gap of the long-term employment practice between small/midsize and large firms, the strong association between educational attainment and employment status (regular and non-regular), heterogeneous situations surrounding job changers, the meaning of certificates and licenses, the relative increase in the income of professionals, and increasing immobility of intergenerational income transmission. Nakazawa, who analyzed the employment situation of youth, describes the situation as follows:

[T] he increase in non-regular workers in their first and second job is noticeable. That is, non-regular workers tend to leave a job or to change jobs because their job security is low in general. This leads to increasing fluidity of the labor market. On the other hand, there is no tendency that the duration of employment of regular workers has become shorter recently. (Nakazawa 2008: 128) 
That is, there is no change in the core of the labor market, but the periphery is increasingly fluid. Thus the level of fluidity seems to be increasing as a whole.

An important research question arises: Why has the level of fluidity been increasing in the periphery of the labor market? As mentioned above, Nagamatsu (2008) points out that income disparity between occupational strata is caused by skill-biased technological change and the suppression of the income of low-skilled workers. This explanation focuses on changes in the relationship between demand and supply in the labor market.

However, another explanation addressing segmentation in the labor market exists. According to the rent hypothesis proposed by Grusky and his colleagues (2008), the recent rapid increase in income gap is attributable to the creation of rent at high strata and the collapse of rent at low strata. They define rent as a gap between actual wage and the wage that would be earned if there were no entry barrier. For example, if only union members may work in a particular job, non-union members who are willing to work at a lower wage than that of union members, cannot get the job. Thus union members earn the difference between the two wages as a rent. Professionals such as lawyers and medical doctors who need an official certificate to get a job also earn rent. Grusky and his colleagues argue that rents at lower strata have been deteriorating due to such factors as the weakening of labor unions, while rents at higher strata have been created by such social closure as the increase in the number of occupations that require official certificates.

The arguments by Nagamatsu (2008) and Grusky and his colleagues (2008) are about income, but they can be applied to job security and benefit packages. Applying them to the labor market in Japan would show that its duality, which is a distinctive feature of it, has been reinforced; that is, higher strata are still protected in the core of the labor market due to increasing demand for them and the creation of rents, while lower strata are trapped in the increasing fluidity of the market periphery due to the deterioration of rents. This complements the theoretical argument, outlined in Section 1, that protective institutions in the internal labor market have larger inertia than those in the external labor market. Protective institutions in Japan have produced rents, and their inertia is large. Thus workers in the internal (core) labor market still enjoy rents, while those in the periphery suffer the deterioration of rents, contributing to the increase in the number of non-regular workers.

The functional theory of social stratification once argued that social stratification exists because it has positive functions in society (Davis and Moore 1945; Parsons 1940). In addition, Hara and Seiyama (2005) point out that social stratification has public values that link individuals' 
motivation to the order of social stratification. However, the emerging characteristic of social stratification in contemporary Japan - the coexistence of stability and increasing fluidity - casts doubt on such social functions and public values. Rather, focusing on class strategies (Ishida and Slater 2010) such as the creation of rents in the labor market would lead to a better understanding and explanation of changes in Japan's social stratification system. ${ }^{4}$

Yoshimichi Sato (ysato@sal.tohoku.ac.jp) is distinguished professor and the director of the Center for the Study of Social Stratification and Inequality at Tohoku University. He is the author of seven books ranging from social change to game theory to social stratification. His current research focuses on inequality between regular and non-regular workers in Japan, on rational choice analysis of the emergence of trust between strangers, and on agent-based modeling of social networking among individuals. Sato's most recent books include Deciphering Stratification and Inequality: Japan and Beyond (2007), Social Stratification and Inequality (in Japanese, 2008), and Game Theory (in Japanese, 2008).

\section{Notes}

* This paper is based on Sato (2009). I thank the Japan Sociological Society for their permission to publish an English version of it. This research was supported by Grant-in-Aid for Specially Promoted Research (1): 16001001 (Principal Investigator: Sato Yoshimichi) and Grant-in-Aid for Scientific Research (A): 20243029 (Principal Investigator: Sato Yoshimichi). Academic support from the Center for the Study of Social Stratification and Inequality at Tohoku University is also gratefully appreciated. Last but not least, the excellent comments of two anonymous reviewers are deeply appreciated.

1. Nippon Keidanren, a major organization of employers in Japan, proposed three types of workers in 1995. These were (1) workers who accumulate skills without fixed-term employment contracts, (2) workers who have specialized skills with fixed-term employment contracts, and (3) flexible workers with fixed-term employment contracts. Even though Nippon Keidanren promotes the second and third types of workers to reduce labor costs and to increase flexibility in employment, it still acknowledges the importance of the first type of workers.

2. Although intergenerational mobility is an important topic in the study of social stratification and social mobility, we do not deal with it in this paper. This is because mobility table analysis does not capture the exact timing when respondents obtained their current jobs and, therefore, contains little information on the current situation of social stratification in Japan. Nevertheless, Ishida's (2008) event history analysis of the subject shows that the likelihood of a person in their mid-career to be a professional or a manager if a parent is also a professional or manager has recently become stronger even after controlling for the effect of education. This finding reveals the stability of the upper strata of professionals and managers.

3. NEETs are young people who are Not in Employment, Education, or Training.

4. See also Hashimoto (2007) for the possible emergence of "a new class society." 


\section{References}

Agata, Kenji. 2008. Shokureki keisei ni okeru shikaku riyōsha no bunseki [An analysis of utilizing vocational qualifications in career formation]. In Kenji Agata (ed.), Hatarakikata to kyaria keisei (2005-nen SSM chosa shirtzu 4) [Work style and career formation (The 2005 SSM research series; 4)], 85-102. Sendai: The 2005 SSM Research Committee.

Aizawa, Shin'ichi \& Satoshi Miwa. 2008. 2005-nen SSM dēta ni okeru keizaiteki fubyōdō shihyō no kisoteki kentō: Setai shanya o chasin ni [Economic inequality of Japanese society: Trends in income distribution in two recent decades]. In Satoshi Miwa \& Daisuke Kobayashi (eds.), 2005-nen SSM Nihon chōsa no kiso bunseki: Közō-süsei-hōho (2005-nen SSM chosa shirtzu 1) [Basic analysis of the 2005 SSM survey in Japan (The 2005 SSM research series; 1)], 95-109. Sendai: The 2005 SSM Research Committee.

Brinton, Mary C. 2008. After the bubble: young men's labor market entry experiences in the 1990s and beyond. In Hiroshi Tarohmaru (ed.), Jakunensō no shakai idō to kaisōka (2005-nen SSM chōsa shirīzu 11) [Social stratification and social mobility of young Japanese (The 2005 SSM research series; 11)], 13-35. Sendai: The 2005 SSM Research Committee.

Davis, Kingsley \& Wilbert E. Moore. 1945. Some principles of stratification. American Sociological Review 10 (2). 242-249.

Grusky, David B., Kim A. Weeden \& Matthew Di Carlo. 2008. The scary takeoff: Why standard accounts of the rise in inequality are wrong (and why we should wish they were right). Palo Alto: Stanford University, Center for the Study of Poverty and Inequality working paper.

Hara, Junsuke \& Kazuo Seiyama. 2005. Inequality amid affluence: Social stratification in Japan. Melbourne: Trans Pacific Press.

Hashimoto, Kenji. 2007. Atarashii kaikyūshakai atarashii kaikyūtōsō: "Kakusa" de sumasarenai genjitsu [New class society and new class struggle]. Tokyo: Kōbunsha.

Hayashi, Yusuke. 2008. Rōdōshijō no ryūdōka to sedainaiidō no kiketsu: Tenshoku ni tomonau chingin henka kōzō no jidaiteki henka [Fluidization of the labor market and consequence of intra-generational mobility: Longitudinal trends on wage changes in job changes]. Shakaigaku Nenpō [Annual Reports of the Tohoku Sociological Society] 37. 59-70.

Hirata, Shuichi. 2008. Hiseiki koyō no zōka to kakusa no kakudai: Ryūdōka to tayōka wa hontō ka [Increase of non-standard employment and the enlarging social divide]. In Yoshimichi Sato (ed.), Ryūdōsei to kakusa no kaisōron (2005-nen SSM chosa shirtzu 15) [Disparities, social fluidity, and social stratification (The 2005 SSM research series; 15)], 133-152. Sendai: The 2005 SSM Research Committee.

Honda, Yuki. 2005. Wakamono to shigoto: "Gakko keiyu no shüshoku” o koete [Young people and employment in Japan: Beyond the "School-mediated Job Search"]. Tokyo: Tokyo Daigaku Shuppankai.

Imai, Jun \& Yoshimichi Sato. Forthcoming. Regular and non-regular employment as an additional duality in Japanese labor market: Institutional perspective on career mobility. In Yoshimichi Sato \& Jun Imai (eds.), Changes in the Japanese welfareemployment regime and inequality. Melbourne: Trans Pacific Press.

Inada, Masaya. 2008. Chōki koyō no suii: Posuto kōdo keizai seichōki sedai to "shūsin koyō" [A study on the transition of long-term employment in post rapid economic growth Japan]. In Hiroshi Takada (ed.), Kaisō-kaikyū kōzō to chii tassei (2005-nen SSM chosa shirtzu 2) [Class structure and status attainment (The 2005 SSM research series; 2)], 99-110. Sendai: The 2005 SSM Research Committee.

Ishida, Hiroshi. 2008. Sedaikan idō e no seizon bunseki apurōchi [Survival analysis of intergenerational mobility]. In Tsutomu Watanabe (ed.), Sedaikan idō to sedai- 
nai ido (2005-nen SSM chosa shirtzu 3) [Intergenerational and intragenerational mobility (The 2005 SSM research series; 3]), 55-74. Sendai: The 2005 SSM Research Committee.

Ishida, Hiroshi \& David H. Slater. 2010. Social class in Japan. In Hiroshi Ishida \& David H. Slater (eds.), Social class in contemporary Japan: Structures, sorting and strategies, 1-29. London \& New York: Routledge.

Iwai, Hachiro. 2008. Sengo Nihon gata raifukōsu no jizoku to henyō (II): Josei no gakureki to raifukosu no bunseki [Stability and change in the post-war Japanese life course (part 2): An analysis of women's education and life course]. In Miki Nakai \& Isamu Sugino (eds.), Raifukosu-raifusutairu kara mita shakai kaiso (2005nen SSM chosa shirtzu 9) [Social stratification from life course and lifestyle perspective (The 2005 SSM research series; 9)], 75-99. Sendai: The 2005 SSM Research Committee.

Kalleberg, Arne L. \& James R. Lincoln. 1988. The structure of earnings inequality in the United States and Japan. American Journal of Sociology 94. 121-153.

Kanbayashi, Hiroshi. 2008. Tenshoku-rishoku riya no jidaiteki henka: Kodo keizai seichoki kara 2005-nen made no sobyo [Longitudinal change of reasons for job changes and job quits in Japan: A description from 1956 to 2005]. In Kenji Agata (ed.), Hatarakikata to kyaria keisei (2005-nen SSM chosa shirtzu 4) [Work style and career formation (The 2005 SSM research series; 4)], 67-84. Sendai: The 2005 SSM Research Committee.

Kanomata, Nobuo. 2008. Baburu hōkai go no shotoku kakusa to shakai kaisō [Income differentials and social stratification after the collapse of the bubble economy]. In Yoshimichi Sato (ed.), Ryadosei to kakusa no kaisoron (2005-nen SSM chosa shirtzu 15) [Disparities, social fluidity, and social stratification (The 2005 SSM research series; 15)], 47-65. Sendai: The 2005 SSM Research Committee.

Kariya, Takehiko. 1991. Gakko-shokugyo-senbatsu no shakaigaku. Kosotsu shashoku no Nihon-teki mekanizumu [Sociology of schools, vocations, and selections: The Japanese mechanism of high school graduates' transition from school of work]. Tokyo: Tokyo Daigaku Shuppankai.

Kosugi, Reiko (ed.). 2002. Jiya no daisho / furtta: Gendai wakamono no shagyo ishiki to kodo [Freeters and the price of freedom: employment awareness and behavior of contemporary youths]. Tokyo: Nihon Rodo Kenkya Kiko.

Kosugi, Reiko. 2003. Furtta to iu ikikata [Freeter as a lifestyle]. Tokyo: Keisō Shobō.

Nagamatsu, Namie. 2008. Shokugyō ni yoru shotoku kōzō no henka: Kyōsōteki sekutā ni okeru chakansō no shotoku rekka [The change of the structure of earnings inequality by occupation: Earnings decrease of middle class in competitive industrial sector]. In Yoshimichi Sato (ed.), Ryūdōsei to kakusa no kaisōron (2005nen SSM chōsa shirizzu 15) [Disparities, social fluidity, and social stratification (The 2005 SSM research series; 15)], 21-46. Sendai: The 2005 SSM Research Committee.

Nakazawa, Wataru. 2008. Jakunen rodoshijo no ryadoka to wa: Seizon bunseki apurochi kara [What is the fluidity of the youth labor market in Japan? Based on survival analysis approaches]. In Yoshimichi Sato (ed.), Ryädosei to kakusa no kaisōron (2005-nen SSM chōsa shirtzu 15) [Disparities, social fluidity, and social stratification (The 2005 SSM research series; 15)], 113-131. Sendai: The 2005 SSM Research Committee.

Nomura, Masami. 1994. Shüshin Kōyō [Life-time employment]. Tokyo: Iwanami Shoten.

Odaka, Kōnosuke. 1984. Rōdō shijō bunseki: Nijū kōzō no Nihonteki tenkai [An analysis of the labor market: Japanese development of the dual structure]. Tokyo: Iwanami Shoten. 
Parsons, Talcott. 1940. An analytical approach to the theory of social stratification. American Journal of Sociology 45 (6). 841-862.

Sato, Kaoru. 2008. Jakunenso no raifuchansu ni okeru hiseikikoyo no eikyo [Nonregular employment of youth and their life chances: Focusing on jobs and marriage]. In Hiroshi Tarohmaru (ed.), Jakunenso no shakai ido to kaisoka (2005-nen SSM chosa shirtzu 11) [Social stratification and social mobility of young Japanese (The 2005 SSM research series; 11)], 67-79. Sendai: The 2005 SSM Research Committee.

Sato, Yoshimichi. 2008. Disparity society theory and social stratification theory: An attempt to respond to challenges by disparity society theory. In Yoshimichi Sato (ed.), Ryadosei to kakusa no kaisoron (2005-nen SSM chosa shirtzu 15) [Disparities, social fluidity, and social stratification (The 2005 SSM research series; 15)], 1-20. Sendai: The 2005 SSM Research Committee.

Sato, Yoshimichi. 2009. Gendai Nihon no kaiso kozo no ryadosei to kakusa [Inequality and fluidization of the social stratification system in contemporary Japan]. Shakaigaku Hyoron [Japanese Sociological Review] 59 (4). 632-647.

Sato, Yoshimichi \& Shin Arita. 2008. Globalization, local institutions, and middle classes: A comparative study of social mobility of middle classes in Japan and Korea. In Shin Arita (ed.), Higashi Ajia no kaiso dainamikkusu (2005-nen SSM chosa shirtzu 13) [Dynamics of social stratification in East Asia (The 2005 SSM research series; 13)], 43-54. Sendai: The 2005 SSM Research Committee.

Takenoshita, Hirohisa. 2008. Labor market and job shift patterns in Japan: Voluntary and involuntary job mobility. In Tsutomu Watanabe (ed.), Sedaikan ido to sedainaiido (2005-nen SSM chosa shirtzu 3) [Intergenerational mobility and intragenerational mobility (The 2005 SSM research series; 3)], 161-186. Sendai: The 2005 SSM Research Committee.

Yoshida, Takashi. 2008a. Shotoku tassei ni taisuru jakunenki kyaria no koka [Young period job mobility and its consequences to income attainment]. In Yoshimichi Sato (ed.), Ryadosei to kakusa no kaisoron (2005-nen SSM chosa shirtzu 15) [Disparities, social fluidity, and social stratification (The 2005 SSM research series; 15)], 99-112. Sendai: The 2005 SSM Research Committee.

Yoshida, Takashi. 2008b. Sedaikan shotoku ido kara mita kikai fubyodo [Inequality of opportunity from a perspective of intergenerational income mobility]. In Tsutomu Watanabe (ed.), Sedaikanido to sedainaiido (2005-nen SSM chosa shirtzu 3) [Intergenerational mobility and intragenerational mobility (The 2005 SSM research series; 3)], 147-160. Sendai: The 2005 SSM Research Committee. 